\title{
Wildlife rehabilitation: A case study of the neo-tropical, opossum Didelphis marsupialis insularis, Allen 1902.
}

\author{
L. Tardieu ${ }^{a *}$ (D), W. Rollock ${ }^{b}$ (D) and G. W. Garcia ${ }^{a}$ \\ ${ }^{\mathrm{a}}$ Open Tropical Forage-Animal Production Laboratory - OTF-APL, Department of Food Production - DFP, Faculty of \\ Food and Agriculture - FFA, University of the West Indies - UWI, St. Augustine, Trinidad and Tobago \\ ${ }^{\text {b}}$ The Wake up and Call Shelter, Stratmore Avenue, Glencoe, Trinidad and Tobago \\ *e-mail:1_tardieu@hotmail.com
}

Received: September 29, 2018 - Accepted: March 6, 2019 - Distributed: August 31, 2020

(With 2 Figures)

\begin{abstract}
Wildlife rehabilitation facilities in the Caribbean region are limited, yet they can provide relevant information on wild populations. Didelphis marsupialis insularis is a popularly hunted, under-studied, neo-tropical marsupial species that is increasingly being admitted for rehabilitation. The aim of this study was 1 . To record the experiences of rehabilitating D. marsupialis insularis in the neo-tropical island of Trinidad and Tobago and 2. To extract and highlight information on the biology of this opossum sub-species. Using admission records, obtained over a roughly four year period, two breeding periods (February to March and August to October) were illustrated. Litter sizes averaged five individuals, with a range of 1 to 8 young. This species was found to be common in urban areas of the country, with dog attacks reported as the major cause for admission. Thus the information recorded by this wildlife rehabilitation facility has provided great insight on the sparsely studied opossum, D. marsupialis insularis.
\end{abstract}

Keywords: Didelphis marsupialis insularis, neo-tropical wildlife, opossum, wildlife rehabilitation.

\section{Reabilitação de vida selvagem: um estudo de caso do gambá neotropical, Didelphis marsupialis insularis, Allen 1902.}

\section{Resumo}

As instalações de reabilitação e assistência à vida selvagem na região neotropical do Caribe são limitadas, mas informações relevantes sobre populações selvagens podem ser obtidas nesses locais. Didelphis marsupialis insularis é uma espécie de marsupial neotropical, subestimada e popularmente caçada; no entanto, essa espécie está sendo cada vez mais admitida para a reabilitação. Os objetivos deste estudo foram: 1. Registrar as experiências de reabilitação de D. marsupialis insularis na ilha neotropical de Trinidad e Tobago; e 2. Extrair e destacar informações sobre a biologia dessa subespécie de gambá. Utilizando registros de admissão, obtidos ao longo de um período de aproximadamente quatro anos, foram mostrados dois períodos de reprodução, de fevereiro a março e de agosto a outubro. O tamanho da ninhada foi em média de cinco indivíduos, variando de um a oito jovens. Comumente encontrado em áreas urbanas do país, os ataques de cães foram relatados como a principal causa de internação dessa espécie. Assim, a informação registrada por essa instalação de reabilitação de vida selvagem forneceu uma grande visão sobre o gambá D. marsupialis insularis, que tem sido pouco estudado.

Palavras-chave: Didelphis marsupialis insularis, fauna neotropical, gambá, reabilitação da vida selvagem.

\section{Introduction}

\subsection{Wildlife rehabilitation}

Wildlife rehabilitation can be defined as "the temporary care of injured, diseased and displaced indigenous animals and the subsequent release of healthy animals to an appropriate habitat in the wild" (Miller, 2000; Fowler and Miller 2007). It can vary in scope from individual rehabilitators, to large, well-equipped and well-staffed, modern animal hospitals (Kirkwood, 2003; Trocini et al., 2008).

Worldwide, wildlife rehabilitation is viewed as a useful conservation tool for protection of 'wild' species (McInnis,
2017). However, wildlife rehabilitation can play a number of other important roles. They can provide knowledge on the biology and behaviour of wildlife species and educate the public on the value of wildlife and the roles they play in healthy ecosystems (Sleeman, 2007).

Additionally they can potentially detect infectious diseases, identify ecological changes and anthropogenic effects and thus act as monitors for wildlife diseases and ecosystem health (Sleeman and Clark Junior, 2003; Trocini et al., 2008). As studies have shown, even the single description of a disease, reported by a wildlife rehabilitator, can be of significant importance by being an early indicator of a disease outbreak in the area (Mörner et al., 2002; Trocini et al., 2008). 
While there are numerous wildlife rehabilitation facilities in developed nations, developing nations, like those in the neo-tropics, have limited wildlife rehabilitation resources (Karesh, 1995). Yet increased hunting and overexploitation of local wildlife have threatened or placed under threat, wildlife populations in these regions (IUCN, 2019). As highlighted above wildlife rehabilitation can provide one form of relief for animals, but more importantly they can provide vital biological information on understudied species and further serve to monitor the population health of widely hunted species.

In the Caribbean islands of Trinidad and Tobago, there are few recognized wildlife rehabilitation centres that focus mainly on indigenous wildlife species. Records from these centres are an unexploited resource that can provide crucial information on the health and status of wildlife populations. This is particularly relevant given the sparse information available on the biology of many Caribbean species. Scientific documentation in the form of case studies are therefore a significant first step in recognizing and utilizing the vital information stored in the notes and accounts of wildlife carers.

\subsection{Didelphis marsupialis insularis}

Locally known as the 'manicou', D. marsupialis insularis is found in the Caribbean region. A common inhabitant of Trinidad and Tobago, this marsupial can be seen in both rural and urban areas (Adesiyun et al., 1998; Vaughan and Hawkins, 1999; Adler et al., 2012). Regarded as a pest species, the 'manicou' is listed as 'Vermin' under the Conservation of Wildlife Act (Trinidad and Tobago, 1963) in the Laws of Trinidad and Tobago, and can therefore, by law, be killed year round on private lands on both islands. As a valuable source of protein for locals, it is a widely sought after and hunted species, and yet very little information has been documented on this native opossum (Banwarie, 2010; Lambie, 2013). The end result is a dearth of knowledge on this species in the Caribbean.

The objectives of this paper were to document one wildlife centre's experience with rehabilitating the neo-tropical D. marsupialis insularis and to highlight important biological information on this species, including the description of a parturition that occurred in captivity.

\section{Material and Methods}

A retrospective study was conducted using data obtained from one rehabilitation shelter, the Wake up and Call Shelter (WUC) located in Trinidad and Tobago $\left(10.6918^{\circ} \mathrm{N}, 61.2225^{\circ} \mathrm{W}\right)$. The WUC is a small facility, ( $<40$ animals a year) that focuses on caring for local wildlife species and particularly specialises in opossum (Didelphis spp.) care. Data was collected from May 2014 to October 2017. The following variables were considered: (age at admission, location the specimens were found, date of admission, sex, litter size, cause of admission, and outcome after treatment). Causes of admission were identified based on those reported at admission and on physical examination. Animal management records on captive held adults were also examined for behavioural information. Descriptive statistics and inferential analyses were used and means \pm SD were provided throughout the manuscript when necessary.

\section{Results}

Over the study period, a total of 150 young opossums were admitted for rehabilitation to the WUC with an average of 37.5 per year. The majority of opossums admitted to the WUC were received from the North-western region of Trinidad $(81 \%, \mathrm{n}=98)$ (Figure 1). The year 2015 held the highest number of admissions $(30 \%, \mathrm{n}=45)$ and over the

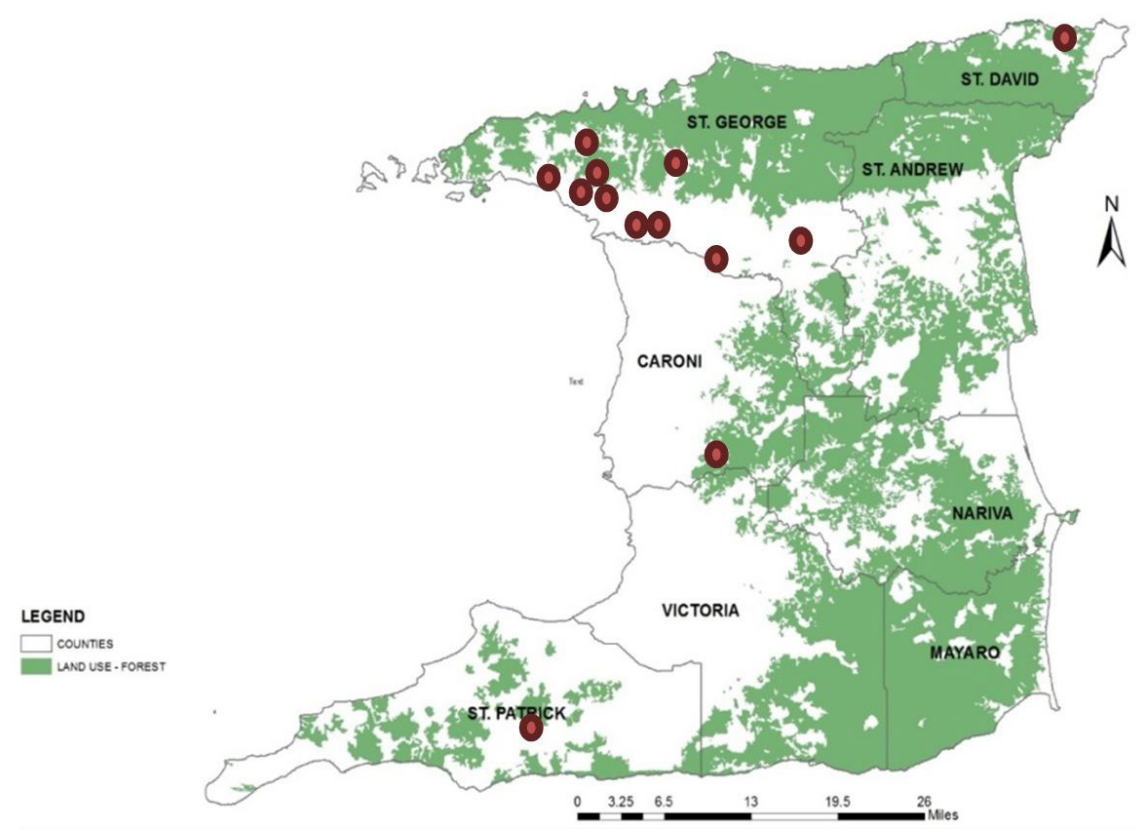

Figure 1. Map of Trinidad showing locations of opossums admitted into the WUC. 
study period the most admitted opossums were newborns less than 1 week old $(20 \%, n=30)$. Litters were usually brought in without their mothers and averaged $(4.69 \pm 2.5$, $\mathrm{n}=32$ ) in size with a range of 1 to 8 young. Based on the ages of the young admitted it was possible to extrapolate the birth months and two breeding periods could be identified (February to March) and (August to October) (Figure 2).

A slightly greater number of young males $(2.45 \pm 1.36$, $\mathrm{n}=76$ ) were admitted, over the total study period, than females $(2.06 \pm 1.75, \mathrm{n}=64)$. The cause of admission was found to be mainly due to dog attacks $(34 \%, \mathrm{n}=51)$, followed by car accidents $(18 \%, \mathrm{n}=27)$ and hunting $(17 \%, \mathrm{n}=26)$ (Table 1$)$.

The three outcomes after admission into the WUC were death, release and kept in captivity. The majority of young opossums that were admitted for care died due to unknown causes $(35 \%, \mathrm{n}=52)$; closely followed by physical damage, probably inflicted while the young were being removed (by human carers) from the mother opossum nipples $(31 \%, \mathrm{n}=46)$ (Table 2). Only a small portion of the total young admitted survived $(29 \%, \mathrm{n}=44)$ and were released, over the four year period $(21 \%, \mathrm{n}=32)$ (Table 2$)$.

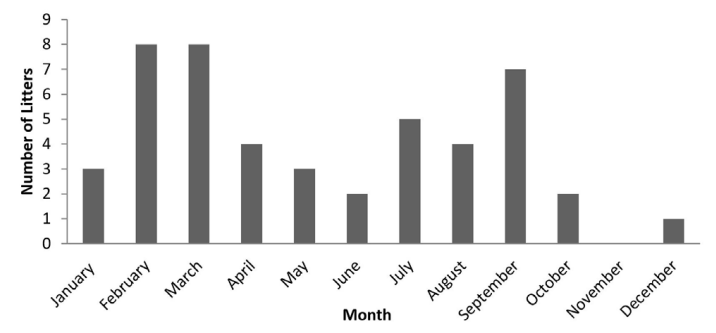

Figure 2. Estimated birth month based on young opossums admitted to the WUC for the period 2014-2017.

Table 1. Causes of admission of D. marsupialis insularis to the WUC over the period 2014-2017.

\begin{tabular}{lcc}
\hline \multicolumn{1}{c}{ Cause of admission } & n & \% \\
\hline Car accident & 27 & 18 \\
Dog attack & 51 & 34 \\
Hunting & 26 & 17 \\
Injured & 3 & 2 \\
Unknown & 41 & 27 \\
Mother abandoned & 2 & 1 \\
TOTAL & $\mathbf{1 5 0}$ & $\mathbf{1 0 0}$ \\
\hline
\end{tabular}

\subsection{Parturition in captivity}

In early July 2016, one breeding episode occurred between two adult, captive opossums. The breeding pair consisted of a female (2-3 years old) and a male (1 year old). Both adults were wild born, but had been brought into WUC as young and retained at the clinic. The WUC at that time held four adult males and one mature female in their care.

Indications that the female was in oestrus, were first observed when the four males produced a series of vocalizations in the form of 'metallic' clicking noises in late June 2016. The female was also noted to have ceased eating around this time. To determine the interest of the female in breeding, the four males were individually introduced to the female in the last week of June 2016. This was done via a 'limited contact' method devised by the WUC, described as follows; males penned individually in smaller cages, were sequentially placed inside the larger female cage. This served to protect the male from highly aggressive behaviours of the female, since females only tolerate males during periods of receptivity.

The female indicated or chose -by lack of aggressive behaviours- the male that she was interested in. This male was then allowed access, via the opening of his cage, within the female's enclosure on the 5th July 2016. The male on entering the female's enclosure proceeded to mark the enclosure. Mating occurred on the first night the male was introduced and the male was removed the next morning (6th July 2016) from the females' enclosure.

Eleven days later (16th July 2016) at $0830 \mathrm{~h}$ (GMT-4), signs of parturition were observed, with the female's stomach displaying abdominal contractions (spasms and movement by the pouch area) in a similar pattern as described by Reynolds (1952). The female was observed on many instances subsequent to this observation licking her pouch area.

In early September 2016, one newborn's tail was observed in the female's pouch. Subsequent observation however, found no more evidence of young in her pouch and it was concluded that the young had died.

\section{Discussion}

Much of the records supplied by the WUC have provided new reproductive and behavioural information on this species. This included breeding periods which

Table 2. Outcome of D. marsupialis insularis admissions into the WUC over the period 2014-2017.

\begin{tabular}{lcc}
\hline \multicolumn{1}{c}{ Outcome } & $\mathbf{n}$ & $\mathbf{\%}$ \\
\hline Cannibalism & 2 & 1 \\
Damaged spine & 1 & 1 \\
Dead on arrival & 5 & 3 \\
Physical damage/removal from mothers' nipples & 46 & 31 \\
Unknown & 52 & 35 \\
Total Deaths & $\mathbf{1 0 6}$ & $\mathbf{7 1}$ \\
Released & 32 & 21 \\
Kept in captivity/Still being treated & 12 & 8 \\
Total Admitted & $\mathbf{1 5 0}$ & $\mathbf{1 0 0}$ \\
\hline
\end{tabular}


were extrapolated using the ages of the young opossums admitted for rehabilitation. Based on this data, at least two defined breeding seasons, February to March and August to October were identified for D. marsupialis insularis and both the mean litter size and range were found to be fairly similar to other South American Didelphis spp. (Tyndale-Biscoe and Mackenzie, 1976; Cabello, 2006).

Over the study period the causes of admission were due to anthropogenic activities and varied from hunting to car accidents to dog attacks. This is supported by recent research, which also identifies anthropogenic factors as one of the most predominant causes of wildlife admissions worldwide (Schenk and Souza, 2014; Molina-López et al., 2017). Dog attacks were the highest cause of admission at the WUC, and may be due to opossums living in residential areas where dogs are commonly found. This is supported by the admission records that list urban areas of Trinidad and Tobago as the primary origin of the admitted individuals.

Similarly congeners of the local opossum namely $D$. albiventris, D. pernigra and $D$. virginiana, have all been noted as being very tolerant of human occupied areas. They have commonly been identified near human dwellings, garbage dumps and agricultural lands (Fonseca et al., 1982; Siciliano, 2013). In contrast, studies show that D. marsupialis appears to avoid human occupied areas (Stallings, 1988; Sunquist and Eisenberg, 1993; Eisenberg and Redford, 1999; Brito et al., 2008).

'Unknown' causes were one of the main reasons for opossum mortality, after admission. One possible explanation could have been illness or diseases that arose due to separation from the mother. Studies have found that newborns are able to obtain passive immunity from viral diseases like vesicular stomatitis through their mother's milk (Trujillo et al., 2010). As the majority of newborns were admitted after the death of their mothers, they may not have been able to obtain the antibodies from their mother's milk and consequently may have had increased susceptibility to diseases.

Another main source of mortality after admission was physical/internal damage caused by human carers while removing young from the female's nipples. This is not unanticipated, as newborns are very vulnerable during the 'fixation period'. At this stage the newborns mouth exhibits partial lip fusion (Krause and Krause, 2006; Hines, 2017 ) and the lips fundamentally tear once the young are removed from the nipples. In addition, their bodies are very fragile so that even with careful handling, damage cannot be totally avoided. One suggestion to reduce this cause of mortality would be to remove the nipple from the female, with the young still attached and using a small tube, feed the young through the nipple. However, this technique requires testing to determine its feasibility. As a result of high mortality after admission, the success rate of releases was considered low.

The one instance of parturition that occurred at the WUC proved both insightful and informative. Although unsuccessful, as far as the authors are aware, this is the first documented instance of the reproductive behaviour and activity of $D$. marsupialis insularis in captivity. Much of the observations of the WUC during this parturition episode, including: the intolerance and aggressiveness of the female against the males, the emission of sexual vocalization, cage marking behaviour by males, and the post birth licking behaviour of the female were similar to previous descriptions on pre- and post-pregnant Didelphis spp. (Hartman, 1923; Farris, 1950; Reynolds, 1952; McManus, 1970; Hunsaker II and Shupe, 1977; Motta et al., 1983; Krause and Krause, 2006). However, the gestation period observed in this study was notably shorter (11 days), as compared with the previously stated gestation period of 12-15 days in captive held $D$. virginiana and D. marsupialis (Hartman, 1928; Eisenberg and Redford, 1999; Johnson-Delaney, 2002; Krause and Krause, 2006).

The clicking vocalizations displayed by males during the females oestrous, were a sign of mating behaviour that was not previously recorded for this species. It has however, been observed in the male North American opossum in association with sexual interaction (Hartman, 1921; Reynolds, 1952; McManus, 1970; OSUS, 2014). The change of eating habits observed in the female, were also not previously stated in the literature and combined with the vocalizations emitted by males, could be used to indicate the readiness of the D. marsupialis insularis female for mating under captive settings.

It can be inferred that the death of the only newborn that had reached the female's pouch was due to starvation. This is supported by Reynolds (1952) who found that it took two or more suckling young to sustain lactation in the female opossum. The small litter size, produced in this case, may have been as a result of the advanced age of the female, which has been shown to affect fertility in North American opossums (Reynolds, 1952).

In conclusion, the data gathered at the facilities of the WUC have provided interesting biological insight into some aspects of the under-studied and increasingly hunted Caribbean 'manicou'. This information, combined with further population studies, can be used to develop effective conservation management plans for this species in the future.

\section{References}

ADESIYUN, A.A., SEEPERSADSINGH, N., INDER, L. and CAESAR, K., 1998. Some bacterial enteropathogens in wildlife and racing pigeons from Trinidad. Journal of Wildlife Diseases, vol. 34, no. 1, pp. 73-80. http://dx.doi.org/10.7589/0090-355834.1.73. PMid:9476228.

ADLER, G.H., CARVAJAL, A., DAVIS-FOUST, S.L. and DITTEL, J.W., 2012. Habitat associations of opossums and rodents in a lowland forest in French Guiana. Mammalian Biology, vol. 77, no. 2, pp. 84-89. http://dx.doi.org/10.1016/j.mambio.2011.11.008.

BANWARIE, R., 2010 [Accessed 23 October 2014]. Food, fun and more at Brasso Seco [online]. Trinidad and Tobago's Newsday. Available from: http://www.newsday.co.tt/features/0,129854.html

BRITO, D., ASTUA DE MORAES, D., LEW, D., SORIANO, P., EMMONS, L., CUARÓN, A.D., HELGEN, K., REID, R. 
and VAZQUEZ, E., 2008. Didelphis marsupialis. In: IUCN. IUCN Red List of Threatened Species. Version 2013.1. United Kingdom: IUCN.

CABELLO, D., 2006. Reproduction of Didelphis marsupialis (Didelphimorphia: Didelphidae) in the Venezuelan Andes. Acta Theriologica, vol. 51, no. 4, pp. 427-433. http://dx.doi.org/10.1007/ BF03195189.

EISENBERG, J.F. and REDFORD, K.H., 1999. Mammals of the neotropics: The central neotropics. Chicago: University of Chicago Press, pp. 49-54.

FARRIS, E.J., 1950. The Opossum. In: E.J. Farris, ed. The care and breeding of laboratory animals. New York: John Wiley and Sons Inc.

FONSECA, G.A.B., REDFORD, K.H. and PEREIRA, L.A., 1982. Notes on Didelphis albiventris (Lund, 1841) of Central Brazil. Ciencia e Cultura, vol. 34, no. 10, pp. 1359-1362.

FOWLER, M.E. and MILLER, R.E., 2007. Zoo and wild animal medicine current therapy. 6th ed. Missouri: Saunders Elsevier, $512 \mathrm{p}$.

HARTMAN, C., 1921. Breeding habits, development and birth of the opossum. In: Smithsonian Institution. Annual report of the Board of Regents of the Smithsonian Institution. Washington, DC: Smithsonian Institution, Publication 2675, pp. 347-364.

HARTMAN, C., 1923. The oestrous cycle in the opossum. The American Journal of Anatomy, vol. 32, no. 3, pp. 353-421. http:// dx.doi.org/10.1002/aja.1000320307.

HARTMAN, C.G., 1928. The breeding season of the opossum (Didelphis virginiana) and the rate of intrauterine and postnatal development. Journal of Morphology, vol. 46, no. 1, pp. 143-215. http://dx.doi.org/10.1002/jmor.1050460106.

HINES, R., 2017 [viewed 29 September 2017]. Taking care of orphaned wild Opossums. 2nd ed. [online]. 2nd Chance.Info. Available from: http://www.2ndchance.info/raisepossum.htm

HUNSAKER II, D. and SHUPE, D., 1977. Behaviour of the New World marsupials. In: D. Hunsaker Ii, ed. The Biology of Marsupials. New York: Academic Press, pp. 279-348. http:// dx.doi.org/10.1016/B978-0-12-362250-1.50011-3 .

INTERNATIONAL UNION FOR CONSERVATION OF NATURE AND NATURAL RESOURCES - IUCN, 2019. [viewed 4 February 2013]. The IUCN Red List of Threatened Species [online] IUCN. Available from: http://www.iucnredlist.org

JOHNSON-DELANEY, C.A., 2002. Reproductive medicine of companion marsupials. The Veterinary Clinics of North America. Exotic Animal Practice, vol. 5, no. 3, pp. 537-553, vi. http:// dx.doi.org/10.1016/S1094-9194(02)00007-5. PMid:12442714.

KARESH, W.B., 1995. Wildlife rehabilitation: additional considerations for developing countries. Journal of Zoo and Wildlife Medicine, vol. 26, no. 1, pp. 2-9.

KIRKWOOD, J.K., 2003. Introduction: wildlife casualties and the veterinary surgeon. In: E. Mullineaux, R. Best and J.E. Cooper, eds. BSAVA Manual of Wildlife Casualties. Gloucester: British Small Animal Veterinary Association, pp. 1-5.

KRAUSE, W.J. and KRAUSE, W.A., 2006. The Opossum: it's amazing story. Columbia: University of Missouri, $80 \mathrm{p}$.

LAMBIE, I., 2013 [Accessed 23 October 2014]. What's After the Manicou Tax? [online]. The Trinidad Guardian Newspaper.
Available from: http://www4.guardian.co.tt/letters/2013-01-22/ what $\% \mathrm{E} 2 \% 80 \% 99$ s-after-manicou-tax

MCINNIS, K., 2017 [Accessed 24 October 2017]. Wildlife Rehabilitation Organizations Come Together for Week of CE [online]. Anaheim: The International Wildlife Rehabilitation Council (IWRC) Available from: https://theiwrc.org/wp-content/ uploads/2017/09/NWRAIWRC-Press-Release-1.pdf

MCMANUS, J.J., 1970. Behaviour of captive opossums, Didelphis marsupialis virginiana. American Midland Naturalist, vol. 84, no. 1, pp. 144-169. http://dx.doi.org/10.2307/2423733.

MILLER, E.A., 2000. Minimum standards for wildlife rehabilitation. 3rd ed. Minnesota: National Wildlife Rehabilitators Association. 77 p.

MOLINA-LÓPEZ, R.A., MAÑOSA, S., TORRES-RIERA, A., POMAROL, M. and DARWICH, L., 2017. Morbidity, outcomes and cost-benefit analysis of wildlife rehabilitation in Catalonia (Spain). PLoS One, vol. 12, no. 7, pp. e0181331. http://dx.doi. org/10.1371/journal.pone.0181331. PMid:28719647.

MÖRNER, T., OBENDORF, D., ARTOIS, M. and WOODFORD, M.H., 2002. Surveillance monitoring of wildlife diseases. Revue Scientifique et Technique (International Office of Epizootics), vol. 21, no. 1, pp. 67-76. http://dx.doi.org/10.20506/rst.21.1.1321. PMid:11974631.

MOTTA, M.D.F.D., CARREIRA, J.C.D.A. and FRANCO, A.M.R., 1983. A note on reproduction of Didelphis marsupialis in captivity. Memorias do Instituto Oswaldo Cruz, vol. 78, no. 4, pp. 507-509. http://dx.doi.org/10.1590/S0074-02761983000400016.

OPOSSUM SOCIETY OF THE UNITED STATES - OSUS, 2014 [viewed 26 April 2018]. Reproduction -Life Cycle [online]. Available from: https://opossumsocietyus.org/general-opossuminformation/opossum-reproduction-lifecycle/

REYNOLDS, H.C., 1952. Studies on reproduction in the opossum, Didelphis virginiana virginiana. University of California Publications in Zoology, vol. 52, no. 3, pp. 223-283.

SCHENK, A.N. and SOUZA, M.J., 2014. Major anthropogenic causes for and outcomes of wild animal presentation to a Wildlife Clinic in East Tennessee, USA, 2000-2011. PLoS One, vol. 9, no. 3, pp. 1-3. http://dx.doi.org/10.1371/journal.pone.0093517. PMid:24686490.

SICILIANO, L., 2013 [viewed 9 July 2013]. Didelphis albiventris: Animal diversity web [online]. Available from: http://animaldiversity. ummz.umich.edu/accounts/Didelphis_albiventris/

SLEEMAN, J.M. and CLARK JUNIOR, E.E., 2003. Clinical Wildlife Medicine: A new paradigm for a new century. Journal of Avian Medicine and Surgery, vol. 17, no. 1, pp. 33-37. http://dx.doi. org/10.1647/1082-6742(2003)017[0033:CWMANP]2.0.CO;2.

SLEEMAN, J.M., 2007. Use of wildlife rehabilitation centers as monitors of ecosystem health. In: M.E. FOWLER and R.E. MILLER. Zoo and wild animal medicine current therapy. Missouri: Elsevier Health Sciences, pp. 97-104.

STALLINGS, J., 1988. Small mammal inventories in an eastern Brazilian park. Bulletin of the Florida State Museum Biological Sciences, vol. 34, no. 4, pp. 153-200.

SUNQUIST, M.E. and EISENBERG, J.F., 1993. Reproductive strategies of the female Didelphis. Bulletin of the Florida Museum of Natural History Biological Sciences, vol. 36, no. 4, pp. 109-140. 
TRINIDAD AND TOBAGO. Ministry of Legal Affairs, 1963. Conservation of Wildlife Act. Trinidad and Tobago: Government of Trinidad and Tobago, Chapter 67:01.

TROCINI, S., PACIONI, C., WARREN, K. and ROBERTSON, I. 2008. Wildlife disease passive surveillance: the potential role of wildlife rehabilitation centres. In: Proceedings of the national wildlife rehabilitation conference. Canberra, ACT, Australia, pp. 1-5.

TRUJILlO, C.M., RODRIGUEZ, L., RODAS, J.D. and ARBOLEDA, J.J., 2010. Experimental infection of Didelphis marsupialis with vesicular stomatitis New Jersey Virus. Journal of Wildlife Diseases, vol. 46, no. 1, pp. 209-217. http://dx.doi. org/10.7589/0090-3558-46.1.209. PMid:20090034.

TYNDALE-BISCOE, C.H. and MACKENZIE, R.B., 1976.

Reproduction in Didelphis marsupialis and D. albiventris in Colombia. Journal of Mammalogy, vol. 57, no. 2, pp. 249-265. http://dx.doi.org/10.2307/1379686. PMid:932567.

VAUGHAN, C.S. and HAWKINS, L.F., 1999. Late dry season habitat use of common opossum, Didelphis marsupialis (Marsupialia: Didelphidae) in neotropical lower montane agricultural areas. Revista de Biología Tropical, vol. 47, no. 1-2, pp. 263-269. 